УДК 622.24.084.34

\title{
DEVELOPMENT AND RESEARCHING OF DRILLING FLUIDS PROPERTIES TO CARRY OUT WORKS UNDER CONDITIONS OF ABNORMALLY HIGH RESERVOIR PRESSURES CKusturova O. ${ }^{1}$, Kusturova A. ${ }^{2}$, Dobrunov D. ${ }^{3}$, Salim M. ${ }^{3}$ Український науково-дослідний інститут природних газів ${ }^{l}$ Харківський Начіональний Університет ім. Каразіна ${ }^{2}$
}

Національний технічний університет «Харківський політехнічний інститут» ${ }^{3}$

\section{Інформація про авторів:}

Кустурова Олена Валеріївна: ORCID: 0000-0001-7495-0234; ekusturova@list.ru; кандидат технічних наук; провідний науковий співробітник відділу техніки і технології буріння; Український науково-дослідний інститут природних газів; Червоношкільна набережна, 20, м. Харків, 61000, Україна.

Кустурова Аліна В'ячеславівна: ORCID: 0000-0001-5876-4087; aliftina212@gmail.com; студентка факультету геології, географії, рекреації і туризму; Харківський національний університет імені В. Н. Каразіна; майдан Свободи, 4, м. Харків, 61022, Україна.

Добрунов Дмитро Свгенович: ORCID: 0000-0002-5648-4740; dmitriydobrunov@gmail.com; старший викладач кафедри видобування нафти, газу і конденсату; Національний технічний університет «Харківський політехнічний інститут»; вул. Багалія, 21, м. Харків, 61002, Україна.

Салім Мустафа: ORCID: 0000-0003-1482-1101; mabihudi91@hotmail.com; студент факультету технології органічних речовин; Національний технічний університет «Харківський політехнічний інститут»; вул. Багалія, 21, м. Харків, 61002, Україна.

The article presents systematization and comparative analysis of the killing the well technologies using fluids based on organic and inorganic salts. Based on its results it was found that the common practice in Ukraine to kill the wells with abnormally high reservoir pressure is to use clay weighted drilling muds.

In order to develop solutions requiring minimum funds for manufacturing of selected reagents, it was specified the list of drilling fluids for further research and development to carry out works under conditions of abnormally high reservoir pressures.

The article shows the results of research of drilling fluids composition such as solubility in acid and corrosive action. Based on those parameters, the optimum types of fluids for Ukrainian fields, with abnormally high reservoir pressure, were chosen.

In Ukraine the number of production wells that are moving to the final stage of development is growing every year, which increases the need for workover operations. Each underground operation of well workover is necessarily accompanied by killing the well with further technological completion after the casing repairing. Qualitative fluid with minimal corrosion action for killing the wells is the key to success in further completion, testing and exploitation.

Key words: drilling; fluid; composition; corrosion; activity; reagent; action.

Кустурова О. В., Кустурова А. В., Добрунов Д. С., Салім М. «Розробка і дослідження властивостей технологічних рідин для проведення робіт в умовах аномально-високих пластових тисків».

В статті представлено порівняння результатів систематизації та аналізу світових технологій глушіння свердловин із використанням технологічних рідин на основі органічних та неорганічних солей. 
На основі його результатів встановлено, що в Україні загальноприйнятою практикою для глушіння свердловин в умовах аномально високих пластових тисків є використання обважнених глинистих бурових розчинів. 3 метою розробки розчинів, які потребують мінімум коштів на приготування з реагентів, обрано для подальшого дослідження перелік рідин для проведення робіт в умовах аномально високих пластових тисків. В статті представлено результати дослідження рецептури, кислоторозкладності та корозійної дії та сформовано висновок щодо застосування найбільш оптимальних типів для українських родовищ 3 аномально високими пластовими тисками. Авторами встановлено, що технологічні рідини, оброблені реагентами рослинного походження, характеризуються здатністю до кислотної деструкції та проявляють меншу корозійну дію по відношенню до обладнання свердловини, ніж розчини хлориду натрію і бішофіту. Кількість свердловин, що переходять до завершальної стадії експлуатації в Україні щороку зростає, що збільшує потребу у капітальних ремонтах свердловин. Підземний капітальний ремонт кожної свердловини обов'язково супроводжується глушінням свердловини з подальшим освоєнням після проведення технологічних операції. Якісні рідини з мінімальною корозійною дією для глушіння свердловин є запорукою успіху при подальшому освоєнні та експлуатації.

Ключові слова: буріння; рідина; рецептура; корозія; активність; реагент; дія.

Кустурова О. В., Кустурова А. В., Добрунов Д. Е., Салим М. «Разработка и исследование свойств технологических жидкостей для проведения работ в условиях аномально высоких пластовых давлений».

В статье представлено сравнение результатов систематизации и анализа мирових технологий глушения скважин с использованием технологических жидкостей на основании органических и неорганических солей.

На основании его результатов установлено, что в Украине общепринятой практикой для глушения скважин в условиях аномально высоких пластовых давлений имеет место применение утяжеленных глинистых буровых растворов. С целью разработки растворов, которые требуют минимум затрат на приготовление реагентов, выбрано для дальнейшего исследования перечень жидкостей для проведения работ в условиях аномально высоких пластовых давлений. В статье представлены результаты исследования рецептуры, кислоторастворимости и коррозионного воздействия и сформирован вывод о применении наиболее оптимальных типов для украинских месторождений с аномально высокими пластовыми давлениями. Авторами установлено, что технологические жидкости, обработанные реагентами растительного происхождения, характеризуются способностью к кислотной деструкции и проявляют меньшее коррозионное воздействие по отношению к оборудованию скважины, чем растворы хлорида натрия и бишофита. Количество скважин, переходящих к завершающей стадии эксплуатации в Украине, каждый год возрастает, что увеличивает потребность в капитальных ремонтах скважин. Подземный капитальный ремонт каждой скважины обязательно сопровождается глушением скважины с дальнейшим 


\section{Технологія машинобудування}

освоением после проведения технологических операций. Качественные жидкости с минимальным коррозионным воздействием для глушения скважин является залогом успеха при дальнейшем освоении и эксплуатации.

Ключевые слова: бурение; жидкость; рецептура; коррозия; активность; реагент; воздействие.

\section{Background}

In modern well-drilling conditions in Ukraine the final stage is the most responsible in terms to get the invested money back. The final goal of building the well is to enter the productive reservoirs preserving their porosity and permeability, their rapid development, and obtaining the maximum inflow of the reservoir fluid. It is known that performing of the final stages of putting wells into production may cause from 30 to $80 \%$ of wells productivity loss. Therefore, there are problems that should be paid attention to. They are devoted to reservoir exploration, field development, stimulation, and workover.

Drilling fluids play a key role while constructing the well and during its operation. They are used at the stages of well completion (penetration and perforation fluids), well reinforcement (buffer fluids), suspending, workover, and servicing operations (kill fluids).

Drilling fluids must provide a successful performance of technological operations which affect the quality of construction, productivity, and operation time of the well. The strictest requirements are set to the quality of drilling fluids especially for those, which contact the reservoir and may affect the well productivity. Well productivity is affected by physicochemical processes, which take place during the production operations (completion, stimulation, suspending, and killing the wells) and reservoir properties.

Nowadays construction and operation of wells in Ukraine is performed under conditions of bottom-hole temperature (BHT) more than $150^{\circ} \mathrm{C}$ and abnormally low reservoir pressure (ALRP), or abnormally high reservoir pressure (AHRP). Moreover Ukraine suffers from the economic crisis. Those circumstances lead to perform a scientific research in the branch of new fluids development from Ukrainian raw materials, which would allow reducing the price of those reagents. Furthermore, while choosing the technological fluid, some factors must be taken into attention: clay swelling decrease, freezing point, corrosion activity, formation fluid compatibility, density (specific gravity), applicational hazard, environmental hazard, etc.

While completing the well there is, sometimes, a need for acid stimulation to rejuvenate the well and to remove the fluid residue. That is why biodegradability and acid degradability of drilling fluids and its components are of great importance. Kill fluids (buffer fluids) based on inorganic salts have a great corrosive activity towards the well equipment. That is caused by their ion composition and thermo-baric conditions at the bottom-hole [1]. Consequently, comprehensive research of the new technological fluids, which are proposed to use in the industry, is needed.

\section{Resent research overview}

To provide the required technological parameters of fluids in Ukraine, UkrNDIgas (Ukrainian Scientific-Research Institute of Gas) implements technological fluids produced in Ukraine, which are 
based on brines treated with natural reagent $[2,3]$. They are presented by: edible, modified, and extruded starches, seed bran, acrylic- and biopolymers, and other derivatives of cellulose.

To provide the required technological parameters of wash liquids in Ukraine, there are technological fluids produced in Ukraine, which are based on synergistic compositions of natural reagents [4]. They are presented by: edible, modified, and extruded starches, seed bran, acrylic- and biopolymers, and other derivatives of cellulose, etc.

The worldwide known technology of killing the wells with ALRP is to use the fluids, based on inorganic salts. Single salt, or salt composition based fluids are used as the brine systems. The upper limit for brine density (specific gravity) depends on its solubility at the working temperature and is grounded on the value of the backpressure on the reservoir. Usually brines are characterized by $\mathrm{pH}$ of 5-6 and presence of chloride-ions. At reservoir temperature and pressure, the abovementioned characteristics cause high corrosion activity of brines, which requires implementation of corrosion inhibitors (e.g. $\mathrm{CaCl}_{2}$, corrosion speed of which is $0.134 \mathrm{~mm} / \mathrm{yr}$. at a temperature of $121^{\circ} \mathrm{C}$, or $\mathrm{CaBr}$, corrosion speed of which is $0.3 \mathrm{~mm} / \mathrm{yr}$.). Corrosion speed is considered to be tolerant if it doesn't exceed 0.125-0.127 mm/yr. (API-standard).

There is also a known technology of kill fluids production for AHPR. These fluids are based on solutions of organic salts of alkali metals stabilized by biopolymers. They do not affect the reservoirs; they are characterized by $\mathrm{pH}$ of 9-11, which minimizes their corrosion activity.

\section{Work objective}

Nowadays, when completing, stimulating, suspending, and killing the wells under AHPR conditions there is a problem of developing of reliable fluids. Unfortunately, the current commonly used method for killing wells in Ukraine under such conditions is to use weighted drilling fluids.

\section{Investigating the composition of brines}

There is a variety of basic brines used in Ukraine with density value up to $2300 \mathrm{~kg} / \mathrm{m}^{3}$. Currently there are several products such as: solutions of calcium bromide, zinc chloride $\left(\mathrm{ZnCl}_{2}\right)$, "BRO-1" fluid (used as blocking fluid for well killing and workover) with density of $1300 \mathrm{~kg} / \mathrm{m}^{3}$, and "BRO-3" fluid (with similar implementation as "BRO-1") with density ofl $600 \mathrm{~kg} / \mathrm{m}^{3}$ produced by "Brom", OJSC, Krasnoperekopsk. "BRO-1" and "BRO-3" fluids also contain corrosion inhibitors and surfactants. So, it is reasonable to perform further development of drilling fluids on the basis of existing basic prototypes.

The sample of "BRO-3" meets the regulations set in Gas Specification: 24.6-21865342014:2008. The parameters are shown in Tab. 1.

Development and research of killing fluids composition was carried out at UkrNDIgas Research Studies Institute according to thermal resistance research method at a temperature of $150{ }^{\circ} \mathrm{C}$ and pressure fall of 35 bar (the experiment was carried out at the HTHP filter press). $\mathrm{CaCl}_{2}$, "BRO-1" and "BRO-3" were chosen as basic brines. One of the important conditions to make the composition is availability of proposed components, their thermal resistance, and their ability to anaerobic and acid destruction. The experimental procedures were carried out with the 
concentrations: for polymers $-1-3 \%$ and for starches $-5-15 \%$. Non-organic colmatant (chalk, ground marble) in amount of 20-60\% was used as a wall-building (plastering) agent. To find out the technological parameters of obtained fluids they were thermostated at a temperature of $150{ }^{\circ} \mathrm{C}$ for 4 and 16 hours respectively.

Table 1 - Technical parameters of "BRO-3" fluid

\begin{tabular}{|c|c|c|}
\hline Parameter & Standard & Actually \\
\hline Appearance & $\begin{array}{c}\text { Solution of yellow of grey } \\
\text { color }\end{array}$ & suits \\
\hline Density, g/cm ${ }^{3}$, higher than & 1,6 & 0,5 \\
\hline $\begin{array}{c}\text { Weight content of insoluble } \\
\text { residue, \%, lower than }\end{array}$ & 0,5 & - \\
\hline $\begin{array}{c}\text { Weight content of calcium } \\
\text { chloride, \%, higher than }\end{array}$ & 15 & - \\
\hline $\begin{array}{c}\text { Weight content of calcium } \\
\text { nitrate, \%, higher than }\end{array}$ & 15 & \\
\hline
\end{tabular}

According to experimental procedures it was ascertained that, under abovementioned conditions and after 16 hours of elapsed time, the most temperature resistant fluid was the fluid based on CMHEC (carboxymethyl hydroxyethyl cellulose). The initial parameters of this fluid before thermostatting: temperature $-160{ }^{\circ} \mathrm{C}$, density (specific gravity) $-1640 \mathrm{~g} / \mathrm{cm}^{3}$, Filtration $=18 \mathrm{~cm}^{3} / 30 \mathrm{~min}$., stability $-75 \%$. Those fluids which consisted of only one structurebuilding component (e.g. xantic gum, or polyacrylamide, or starch, or SWL) showed worse thermal resistance. The highest resistance was noticed in fluids with complex processing, e.g. extruded starch + xantic gum, or extruded starch + polyacrylamide, or xantic gum + CMHEC, or xantic gum + polyacrylamide. These fluids showed 90-95\% stability after 24 hours since preparing. After thermostatting their stability was at the level of $80-85 \%$, and their technological parameters were in the range of acceptable values.

\section{Research in acid destruction of model fluids}

The investigated compositions were created on the basis of $\mathrm{CaCl}_{2}\left(\right.$ density $\left.-1.3 \mathrm{~g} / \mathrm{cm}^{3}\right)$, "BRO-1" (density $-1.3 \mathrm{~g} / \mathrm{cm}^{3}$ ), and "BRO-3" (density $-1.6 \mathrm{~g} / \mathrm{cm}^{3}$ ) brines. All of the brines contained $5-20 \%$ of acid soluble solid phase, which is used to create a filter cake at the well bore zone and avoid fluid absorption while killing the well. While well completion by wellbore cleaning out it is very hard to remove the residual colmatant agent and the residual fluids as they experience significant changes under the conditions of high temperature and pressure.

According to the research the "BRO-3" fluid shows parameters as follows: viscosity $70 \mathrm{cSt}$. (at $20^{\circ} \mathrm{C}$ ), $\mathrm{pH}=6\left(\right.$ at $20^{\circ} \mathrm{C}$ ), $\mathrm{pH}=5.8$ (at $90^{\circ} \mathrm{C}$ ), no solid and colloid phase containing, no residue after mixing with technical water, thermal resistance at temperatures from -15 to $+150{ }^{\circ} \mathrm{C}$.

To investigate the effect of acid on the developed fluids destruction it was carried out the express-test using $15 \%$ solution of $\mathrm{HCl}$ and samples of fluids No. 1-3. The results are shown in Fig. $1-4$ respectively. 


\section{Технологія машинобудування}

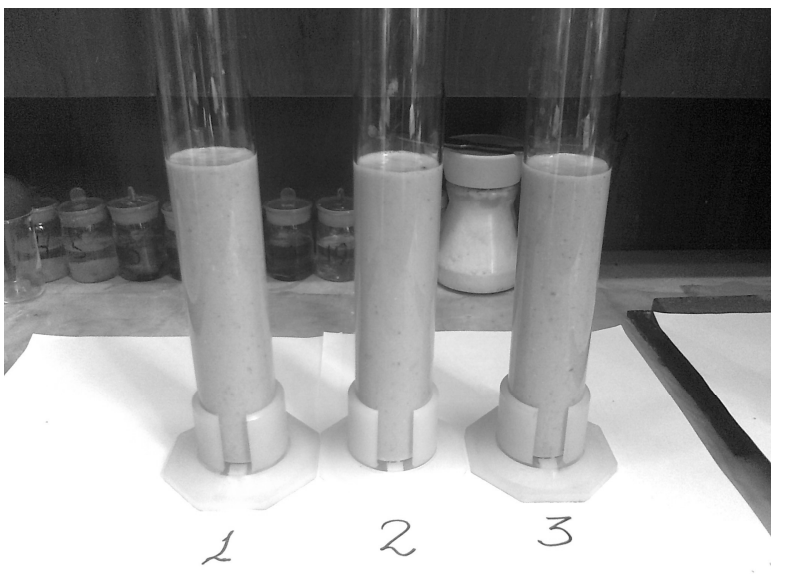

Fig. 1 - No.1 Solution of $\mathrm{CaCl}_{2}+13 \%$ polymer composition $+5 \%$ chalk; No. 2 "BRO-1" $+7 \%$ polymer composition $+10 \%$ chalk;

№3 "BRO-3" $+14 \%$ polymer composition $+20 \%$ chalk

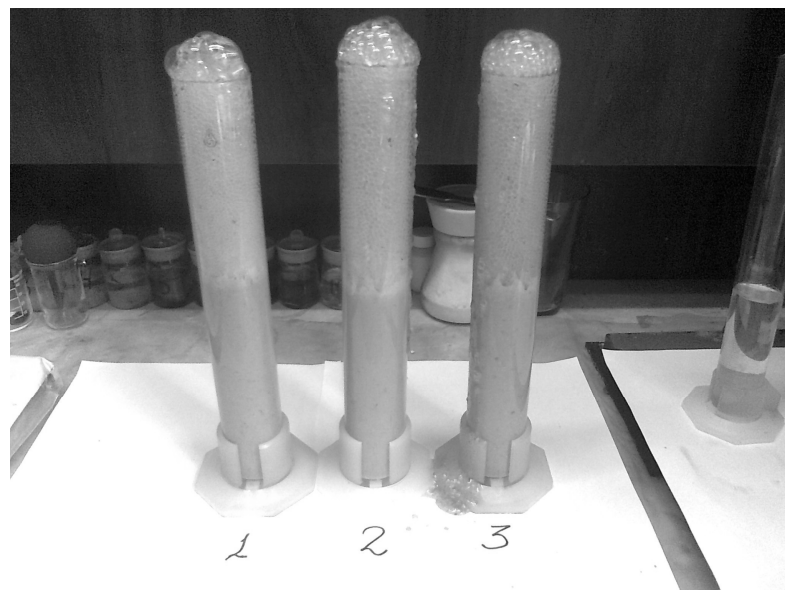

Fig. 3 - 5 minutes after starting the experiment

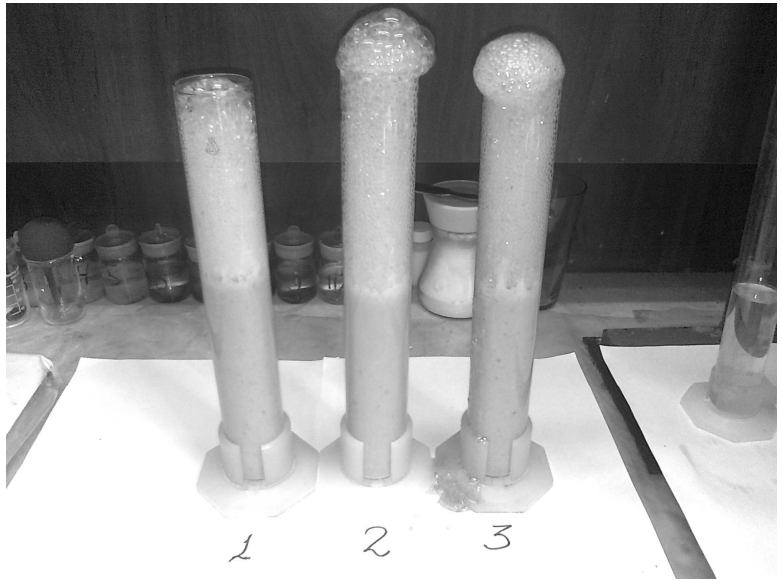

Fig. 2 - No. $1+10 \% \mathrm{HCl}(15 \%)$; No. $2+10 \% \mathrm{HCl}(15 \%)$; No. $310 \%+\mathrm{HCl}(15 \%)$

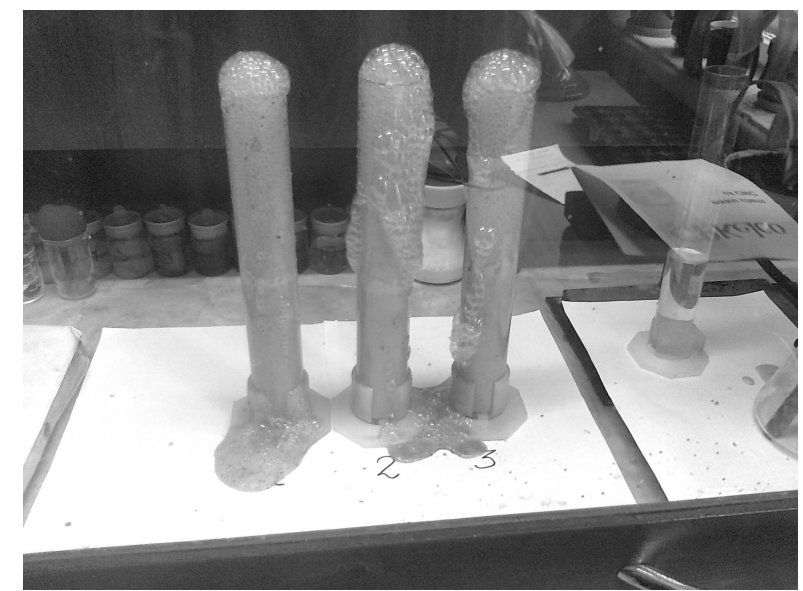

Fig. $4-7$ minutes after starting the experiment

The express-test shows the ability of the developed fluids to acid destruction under normal conditions. It should be noted that under high temperature and high pressure the reaction would proceed more intensively. That would cause qualitative cleaning of the bottom-hole zone of production reservoirs.

\section{Investigation of basic brines corrosion action}

Gravimetric method [5] was used to investigate the corrosion rate in mineralized fluids. The method is based on weight measuring of the pilot joints with the dimensions of $30 \times 15 \times 2 \mathrm{~mm}$, made of R-110-steel (the material of which tubing is made), before and after holding them into model environments under normal conditions for 90 days. The samples were pre-polished and defatted according to the common used methods [6].

The following model environments were investigated:

-Sodium chloride solution (perfect $\mathrm{NaCl}$ solution);

-Bischofite solution, obtained from Eastern-Poltava deposits;

-"BRO-1" fluid; 


\section{Технологія машинобудування}

-"BRO-3" fluid;

Corrosion rate according to corrosion depth index $\left(\mathrm{k}_{\mathrm{h}}, \mathrm{mm} / \mathrm{yr}\right.$.) and weight corrosion index $\left(\mathrm{k}_{\mathrm{m}}, \mathrm{g} /\left(\mathrm{cm}^{2} \cdot\right.\right.$ year $\left.)\right)$ are shown in Fig. 5-6.

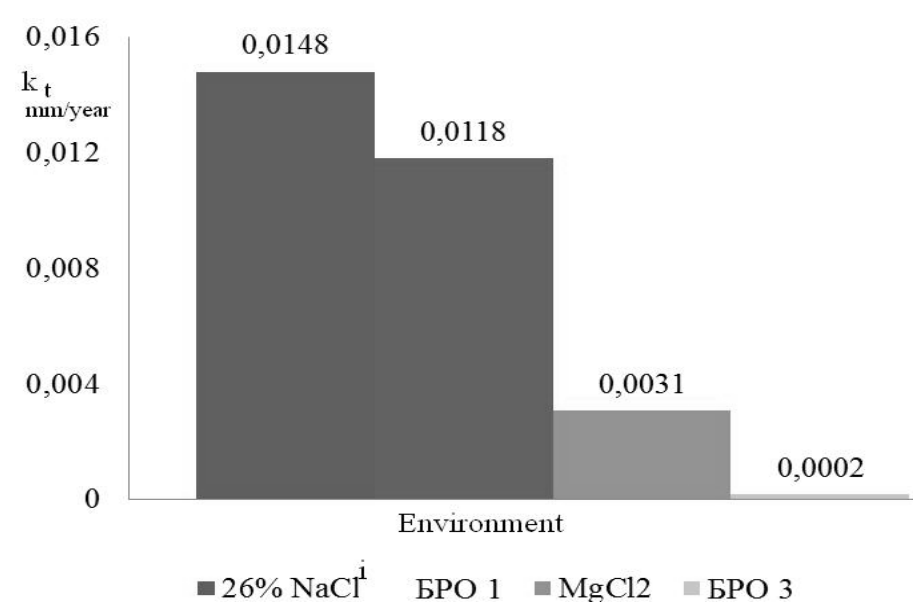

Fig. 5 - Corrosion depth index for different model environments

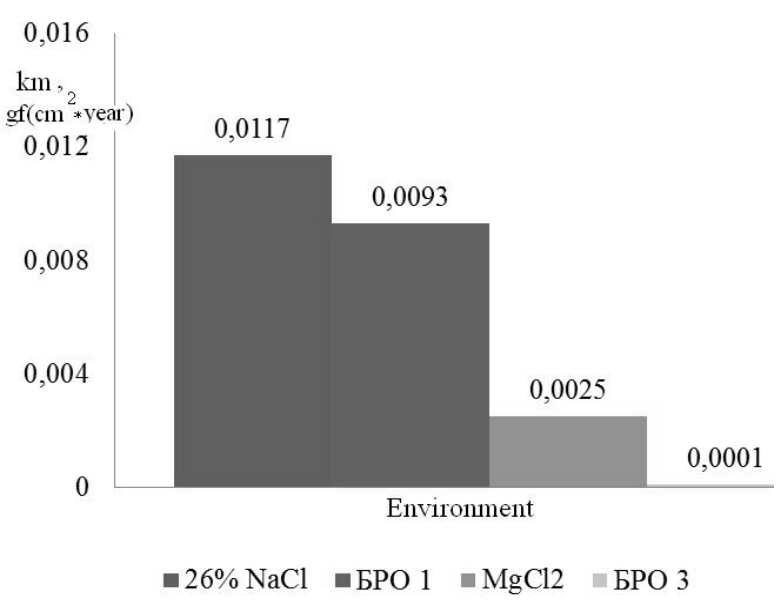

Fig. 6 - Weight corrosion index for different model environments

According to Fig. 5 and $6 \mathrm{NaCl}$ solutions showed higher corrosion activity, which is explained by high contain of chloride ions that cause higher corrosion rate [5]. That is confirmed by thick film of corrosion products on the top of metal sample (Fig. 7).

Corrosion rate in the environment of "BRO-1" (an inorganic salt solution with density of $1.3 \mathrm{~g} / \mathrm{cm}^{3}$ ) is relatively significant too, but there is a hard black oxidation film formed under the layer of corrosion products (Fig. 7, photo $b$ ). So there is a possibility of metal immunization and it may cause the slow-down effect of corrosion $[6,7]$.

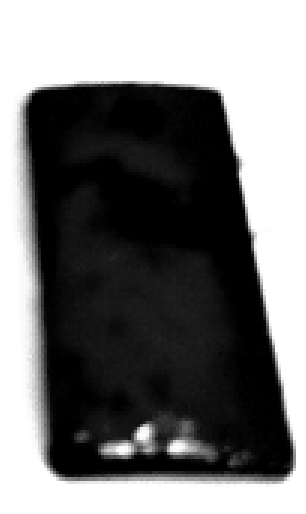

a

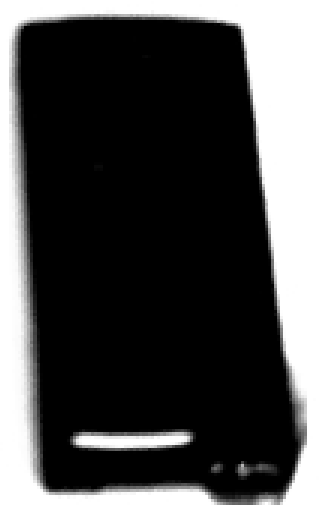

b

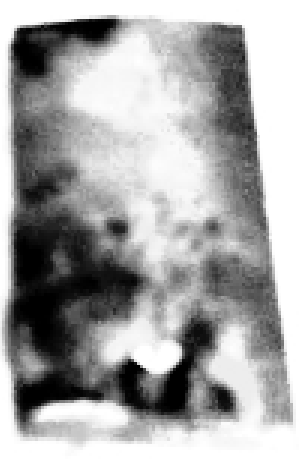

c

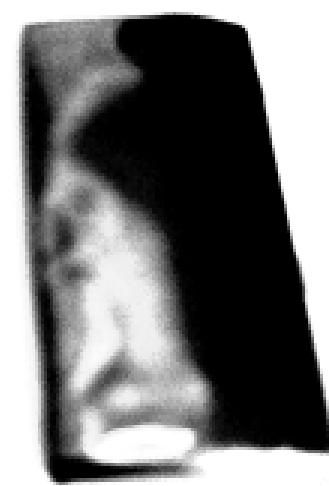

d

Fig. 7 - Samples photos after investigating the effect of different environments:

a) $26 \% \mathrm{NaCl}, \mathrm{b}$ ) "BRO-1", c) Bischofite, d) "BRO-3"

The pilot joint placed into the environment of "BRO-3" fluid (the composition of inorganic salts in water) experienced the least corrosion influence. It should be noted that during the overview of the sample there were no signs of both general and pitting corrosion. That fact can be explained by fluid component and quantitative composition, which caused hard oxidative film formation and, as a result, metal immunization. 


\section{Results}

The investigated fluids based on brines with density of $1300-1600 \mathrm{~kg} / \mathrm{m}^{3}$, treated with natural reagents show ability to acid destruction, and show lower corrosion activity comparing with $\mathrm{NaCl}$ and bischofite. Therefore, technological fluids developed by UkrNDIgas Research Studies Institute may be recommended to provide works under AHRP conditions. In Ukraine the number of production wells that are moving to the final stage of development is growing every year, which increases the need for workover operations. Each underground operation of well workover is necessarily accompanied by killing the well with further technological completion after the casing repairing. Qualitative fluid with minimal corrosion action for killing the wells is the key to success in further completion, testing and exploitation. This year's proposed fluids will be tested at Shebelynka gas-condensate field.

\section{References}

1. Токунов В. И. Технологические жидкости и составы для повышения продуктивности нефтяных и газовых скважин / В. И. Токунов, А. 3. Саушин. - М. : Недра, 2004. - 711 с.

2. Васильченко А. О. Інгібовані бурові розчини: аналіз, проблеми i тенденції їх розвитку / А. О. Васильченко, М. А. Мислюк // Нафтова і газова промисловість. - 2006. - № 4. - С. 7-11.

3. Васильченко А. О. Малоглинисті системи бурових розчинів на основі синергетичних сумішей / А. О. Васильченко, О. В. Кустурова, М. В Гордійчук // Питання розвитку газової промисловості України. 2004. - Вип. XXXII. - С. 161-162.

4.Пат. №22280А Україна, МПК(2006) С09К8/42; Е21В21/00;Е21B33/138. Розчин для глушіння свердловин / Ю. В. Лубан, А. Г. Розенгафт, І. Ю. Харів ; власник Наук. досл. ін-т. технології буріння. № 96051768, заявл. 05.05.1996, опубл.30.06.1998, бюл. № 3. -4 с.

5. ГОСТ 9.908-85. Единая система защиты от коррозии и старения. Металлы и сплавы. Методы определения показателей коррозии и коррозионной стойкости. - Введ. 1985-10-31. - М. : Изд-во стандартов, 1986. - 17 с.

6. Семенова И. В. Коррозия и защита от коррозии / И. В. Семенова, Г. М. Флорианович, А. В. Хорошилов. - М. : Физматлит, 2002. -335 с.

7. Розенфельд И. Л. Ингибиторы коррозии / И. Л. Розенфельд, М. : Химия, 1977. - 352 с.

\section{References}

1. Tokunov, V \& Saushin, A 2004, Tekhnologicheskiye zhidkosti i sostavy dlya povysheniya produktivnosti neftyanykh i gazovykh skvazhin, Nedra, Moskva.

2. Vasylchenko, A \& Mysliuk, M 2006, 'Inhibovani burovi rozchyny: analiz, problemy i tendentsii yikh rozvytku', Naftova i hazova promyslovist, no. 4, pp. 7-11.

3. Vasylchenko, A, Kusturova, O \& Hordiichuk, M 2004, 'Malohlynysti systemy burovykh rozchyniv na osnovi synerhetychnykh sumishei', Pytannia rozvytku hazovoi promyslovosti Ukrainy, iss. XXXII, pp. 161-162.

4. Luban, Iu, Rozenhaft, A \& Khariv, I 1996, Rozchyn dlia hlushinnia sverdlovyn, UA Patent 22280A.

5. Gosudarstvennyy komitet SSSR po standartam 1985, Edinaya sistema zashchity ot korrozii $i$ stareniya. Metally $i$ splavy. Metody opredeleniya pokazateley korrozii i korrozionnoy stoykosti, GOST 9.908-85, Izdatelstvo standartov, Moskva.

6. Semenova, I, Florianovich, G \& Khoroshilov, A 2002, Korroziya i zashchita ot korrozii, Fizmatlit, Moskva.

7. Rozenfeld, I 1977, Ingibitory korrozii, Khimiya, Moskva.

Стаття надійшла до редакції 8 листопада 2016 р. 